Vol. 14 (2005): 112-121.

\title{
Successive alkalinity producing system for the treatment of acid sulphate soil runoff: preliminary results of a field trial
}

Virve Kustula, Allan Witick and Jarmo J. Meriläinen

Institute for Environmental Research, FI-40014 University of Jyväskylä, Finland, e-mail: virve.kustula@ymtk.jyu.fi

\begin{abstract}
A successive alkalinity producing system (SAPS) has been investigated as a potential passive treatment option for acid, metal containing runoff from acid sulphate soil. A pilot-scale system was installed at an agricultural land site in Rintala embankment area in mid-western Finland. The experimental layout consists of three parallel treatment units: two different SAPS cells and one limestone-filled cell for comparison of performance. The SAPS cells are composed of a bottom layer of limestone and a top layer of compost supplemented with sand. One of the SAPS cells contains sulphate-rich, waste gypsum mixed with the compost layer in order to enhance the metal reduction by sulphate reducing-bacteria. Over a 3 year period on average between 6-12 $1 \mathrm{~min}^{-1}$ of water from a nearby drain receiving acid drainage was directed to the system. The quality of the influent water was highly variable: $\mathrm{pH} 4.1-7.1$, aluminium $0.061-29 \mathrm{mg} \mathrm{l}^{-1}$, iron $0.046-22 \mathrm{mg}$ $1^{-1}$, manganese $1.9-23 \mathrm{mg} \mathrm{l}^{-1}$. Flow through the cells increased the $\mathrm{pH}$ and decreased the acidity and concentrations of $\mathrm{Al}$ and $\mathrm{Fe}$. Manganese concentrations did not change significantly $(\mathrm{P}<0.05$, paired t-test) in any of the treatment cells. The current results do not demonstrate the advantages of a SAPS system when compared to a limestone bed and the present implementation is not considered to be an effective treatment method for acid drainage water. Therefore, to increase the alkalinity production of SAPS cells, the system will be modified to increase the contact time of water with limestone.
\end{abstract}

Key words: aluminium, acid sulphate soils, iron, manganese, successive alkalinity producing system, water treatment

\section{Introduction}

Acid sulphate soils are common on the west coast of Finland where post-glacial isostatic land uplift is exposing sediments accumulated during the Lit- torina period of the Baltic Sea. The acid sulphate soils in Finland are extensively used for agricultural production. When the iron sulphides in these soils are exposed to oxygen during, e.g. drainage work, the generation of sulphuric acid can cause acidification of soil and surface and groundwater, 
Vol. 14 (2005): 112-121.

resulting in high concentrations of metals in the runoff (Palko 1994, Peltola and Åström 2002, Joukainen and Yli-Halla 2003). In addition to adverse impacts on agricultural practices, runoff from acid sulphate soils also has a harmful effect on aquatic communities (Meriläinen 1989, Hudd and Kjellman 2002).

The drainage directions for acid sulphate soils (Palko et al. 1988) suggest control of the watertable and surface liming. These methods may be satisfactory for the agricultural use of the soil but are in general ineffective to prevent acid episodes in receiving watercourses. Therefore direct neutralization of drainage water is also recommended in drainage directions if watercourses are to be protected. According to Lähetkangas (1995) liming of water is seen as the only effective way to reduce acidity of River Kyrönjoki. However, costs of liming are high; in addition to the investment costs the annual operating costs are substantial. Moreover, the high amounts of lime needed to neutralize the acidity may lead to clogging of the river or stream bed immediately downstream of the liming station as a consequence of formed precipitates and insoluble liming material (Huttu and Koskenniemi 1998). Liming is also a major perturbation of an aquatic ecosystem, which is likely to affect the quality and dynamics of many of its components. Direct liming of streams using lime can be unsafe to biota due to rapid fluctuations in the $\mathrm{pH}$ value of treated water and the risk of resolubilisation of formed metal sludge (Weatherley 1988).

The origin and chemistry of acid sulphate soil runoff, with high concentrations of aluminium, iron, manganese and sulphates, is similar to that of acid mine drainage and therefore amenable to for similar treatment methods. To address the high operating and maintenance costs of direct liming, passive treatment methods, which utilize natural biological and chemical processes, have been developed mainly in United States since late 1970s for treatment of acid drainage water from mining areas. These developments include compost wetlands, anoxic limestone drains (ALDs) and the successive alkalinity producing system (SAPS). Treatment of acid mine waters using passive sys- tems has found increasing application and hundreds of these systems have already been implemented (Hedin 1997).

Kepler and McCleary (1994) first proposed the SAPS concept in the early 1990s. Successive alkalinity producing systems are combined verticalflow and aerobic wetlands originally developed and used for treatment of acid mine drainage. In the SAPS system alkalinity is produced in a controlled fashion without $\mathrm{pH}$ extremes through bacterial sulphate reduction and limestone dissolution. In temperate regions, the contribution of biological processes to overall alkalinity production is seasonal, while abiotic processes occur at a relatively constant rate. The metals are removed through precipitation and settling in aerobic ponds following the SAPS cells before the treated water is discharged (e.g., Kepler and McCleary 1994, Nairn and Mercer 2000, Jage et al. 2001).

In this paper, the preliminary performance of a new application of a SAPS-type wetland treatment system for acid sulphate soil runoff is presented and discussed. Constructed wetland systems have not, so far as we know, previously been used for treatment of acid sulphate soil runoff.

\section{Material and methods}

Based on promising results from previous laboratory tests (Kustula 2000) a pilot-scale treatment system was constructed in November 2001 at the acid sulphate soil area in Rintala embankment area in Ilmajoki, mid-western Finland, where the soils have been drained since the late 18th century for agricultural purposes. The embankment lies within the catchment area of the river Kyrönjoki, which from time to time is characterised by severe acidity. The geology and geochemistry of the area has been extensively studied by, e.g., Österholm and Åström (2002).

The treatment system consists of three parallel treatment cells: two SAPS cells (Cells 2 and 3 ) and one control limestone-filled cell (Cell 1). One of the SAPS cells (Cell 2) contains waste gypsum, a 


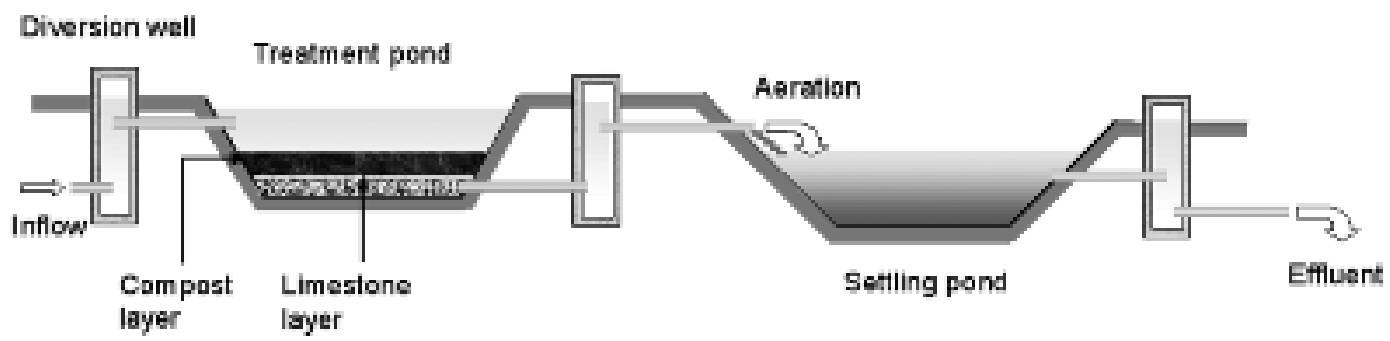

Fig. 1. Design of the successive alkalinity producing system cells.

by-product from the production of titanium oxide pigments, mixed with the compost layer to improve the conditions for microbial sulphate reduction processes. Following each of the three treatment cells, the water is oxygenated in cascade aerators followed by individual settling ponds. Figure 1 illustrates the design of the SAPS cells and Figure 2 the layout of the system. Each SAPS cell consists of a bottom layer of limestone and a top layer of compost material supplemented with sand: construction details of the cells are shown in Table 1 . The standing water column provides water head needed to drive water through the underlying compost substrate which, in turn, is designed to remove any oxygen left in the water and to generate alkalinity via biological reactions. The bottom layer of limestone is designed to add further alkalinity to the water by limestone dissolution. The total surface area of each of the cells is $15 \mathrm{~m}^{2}$, and the areas of the subsequent settling ponds are also $15 \mathrm{~m}^{2}$. On average between $6-121 \mathrm{~min}^{-1}$ of water from a nearby drain receiving acid drainage is pumped to the system. Water levels in each of the treatment cells are controlled by elevation of the exit flow. An arrangement for periodic flushing of the limestone layer was designed in the pilot system because gelatinous aluminium hydroxide

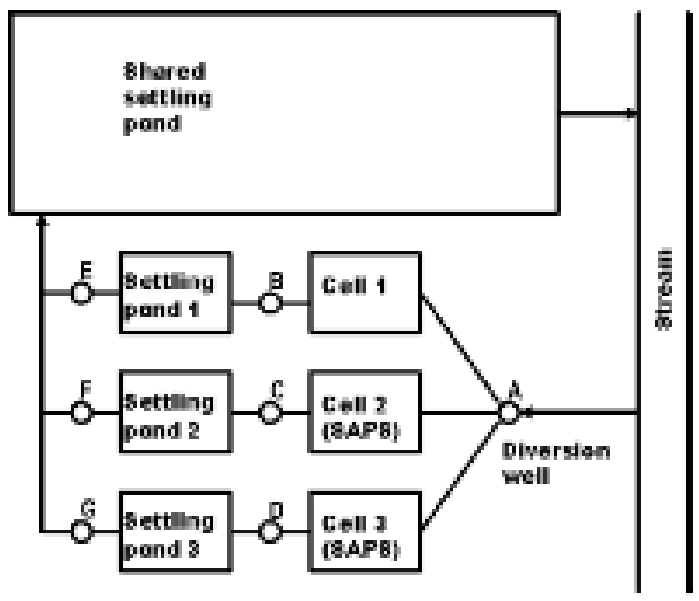

Fig. 2. Layout of the pilot system. Water samples were collected from the diversion well (A) representing influent water, from outflow of each treatment cell (B-D), and outflow of each settling pond (E-G).

may clog the void spaces between the limestone rock used in reactors (Gusek and Wildeman 2002).

Water samples were collected weekly at seven locations except during winter and early spring when there is no flow through the system. The sampling locations included the inflow to the pilot

Table 1. Sizing of treatment cells

\begin{tabular}{lccc}
\hline & Cell 1 (limestone cell) & Cell 2 & Cell 3 \\
\hline Water, cm & 100 & 100 & 100 \\
Compost layer, cm & -- & 50, mixed with gypsum & 50 \\
Limestone layer, cm & 90 & 40 & 40 \\
\hline
\end{tabular}


Vol. 14 (2005): 112-121.

system (diversion well, A) and outflow of each treatment cell (B-D) before aeration and outflow (E-G) of each settling pond as shown in Figure 2. During 2001 samples were taken on three different occasions until the beginning of December when the system froze. No samples were taken during the winter months. In 2002, the sampling period was from May to September, in 2003 from May to October and the number of sampling occasions was 10 and 16 respectively. 2002 was a year of exceptionally low rainfall and, especially during the summer months, there was very low flow through the pilot system. In the beginning of July 2002, the pipes and wells in the SAPS ponds were flushed to remove precipitated metal sludge. The individual settling ponds were found to be too small and a larger shared settling pond was built in the autumn of 2002 to allow a longer period for the settling of precipitates. Inflow rates into the system was designed to be kept at $6-12 \mathrm{~m}^{3} \mathrm{~d}^{-1}$ but, due to clogging of the control wells, the flow rates were periodically increased to $18 \mathrm{~m}^{3} \mathrm{~d}^{-1}$ in the spring of 2002. During the summers of 2002 and 2003 the water level in the feeding stream was very low and very little water was directed into the cells.

The parameters monitored in water samples were $\mathrm{pH}$, acidity, total (non-filtered) and soluble (filtered $0.45 \mu \mathrm{m}$ ) concentrations of iron $(\mathrm{Fe})$, aluminium (Al), manganese (Mn), magnesium, calcium, sodium, potassium, zinc (Zn), nickel (Ni), copper $(\mathrm{Cu})$, chromium $(\mathrm{Cr})$, cadmium $(\mathrm{Cd})$, and lead $(\mathrm{Pb})$, dissolved oxygen, sulphate, suspended solids and the nutrients (total nitrogen, ammonium nitrogen, sum of nitrite and nitrate nitrogen and total phosphorus). The metal analyses were performed at the University of Jyväskylä by inductively coupled plasma atomic emission spectrometry, ICP-AES (Jobin Yvon Horiba Ultima 2) according to standard SFS-EN ISO 11885:1998. All other parameters were analysed by the West Finland Regional Environmental Centre Laboratory in Vaasa, Finland, using standard methods for water analysis (SFS 3021:1979 for pH, SFS 3005:1981 for acidity, SFS-EN 25813:1993 for dissolved oxygen, SFS-EN ISO 10304-1:1995 for sulphate, SFS-EN 872:1996 for suspended solids, flow injection analysis, FIA, technique for total nitrogen and sum of nitrate and nitrite nitrogen, SFS 3032:1976 for ammonia nitrogen and SFS 3026:1986 for total phosphorus). All analyses are accredited according to SFS-EN ISO/IEC 17025 in respective laboratories. In this paper, only the main results from the study period are presented and discussed.

\section{Results and discussion}

The quality of the inflow water was characterised by large seasonal fluctuations: the water was, with the exception of 2002, mostly acidic from the spring to mid summer and neutral during the late summer and autumn with occasional short periods of low $\mathrm{pH}$. Concentrations of aluminium, manganese and sulphate in the influent followed the seasonal variations in acidity with the maximum concentrations measured during periods of low $\mathrm{pH}$. In contrast, concentration of iron was highest when the $\mathrm{pH}$ of the influent water was circumneutral. Results for the most important influent and effluent water quality parameters are shown in Figures $3-5$. There were no major differences in the results between the two SAPS cells and therefore only the results from Cell 3 are presented.

Flow through the cells decreased the acidity of the water. During the most acid periods (influent $\mathrm{pH}<5)$ the $\mathrm{pH}$ increased significantly $(\mathrm{P}<0.05$, paired t-test): the median increase was about one unit in the SAPS cells and about two units in the limestone cell. However, the alkalinity generation of both SAPS cells was insufficient for adequate treatment of the most acid water. The thickness of the limestone layer in the SAPS cells is less than half of the limestone cell and as the flows to each cell were similar the contact time of the water with the limestone was considerably less in the SAPS cells. It was concluded that the residence time for the water should be increased in the SAPS cells either by limiting the water flow or increasing the thickness of the limestone layer.

The highest loading rates of metals occur during maximum flow in the spring season when the 

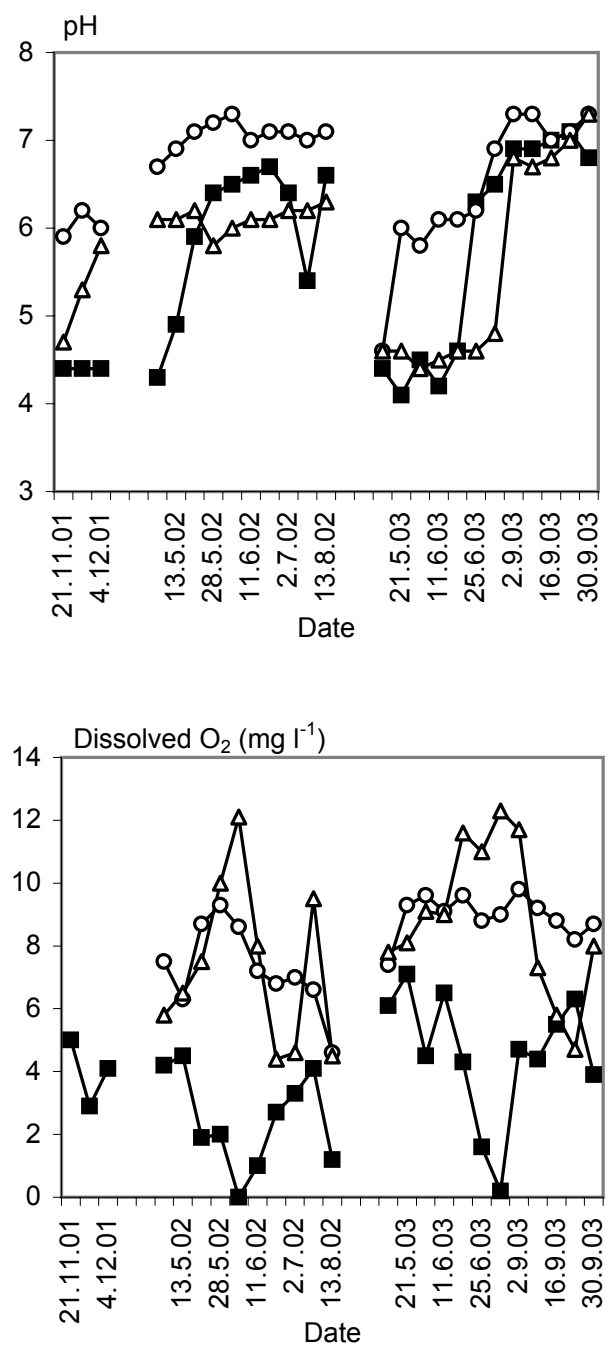

soils are flushed although for iron the maximum concentrations are reached later during drier conditions. For $\mathrm{Al}$ and $\mathrm{Fe}$ even at the highest loading rates $75-80 \%$ of the total aluminium load and 30$80 \%$ of the total iron load was removed in the SAPS cells. There was no significant $(\mathrm{P}<0.05$, paired t-test) difference in effluent quality between the two SAPS treatment options. For the reference limestone cell $60-90 \%$ of the total aluminium load and $60-95 \%$ of the total iron load was removed. It was also noted that the major part of the effluent $\mathrm{Al}$

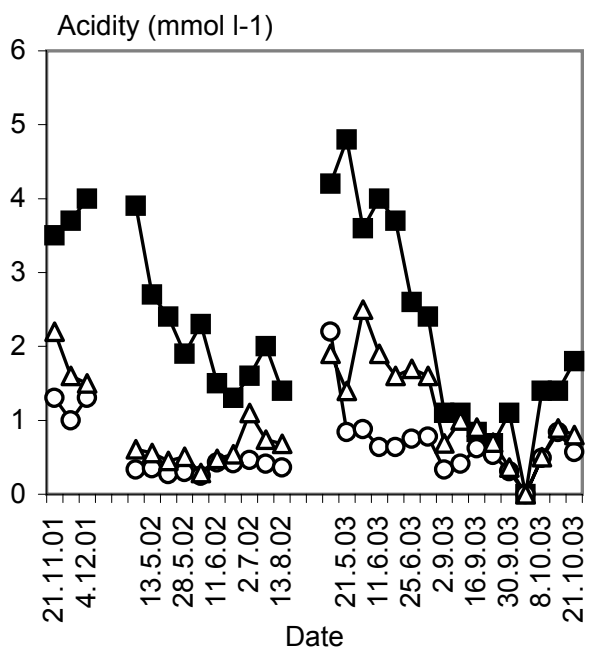

Fig. 3. pH, acidity and oxygen concentrations in the influent to and effluents from the treatment cells $(\boldsymbol{\square}=$ influent water, $O=$ effluent from limestone cell, $\Delta=$ effluent from SAPS cell).

and $\mathrm{Fe}$ in all of the cells was in particulate form, which indicated that the individual settling ponds were not large enough for the settling of the precipitates to occur.

High concentrations of aluminium in acid sulphate soil runoff was expected to be problematic for SAPS because of the formation of gelatinous aluminium hydroxide which may clog the void spaces between the limestone rock used in reactors (Gusek and Wildeman 2002). Until the present, clogging of the system has not been a major main- 
Vol. 14 (2005): 112-121.
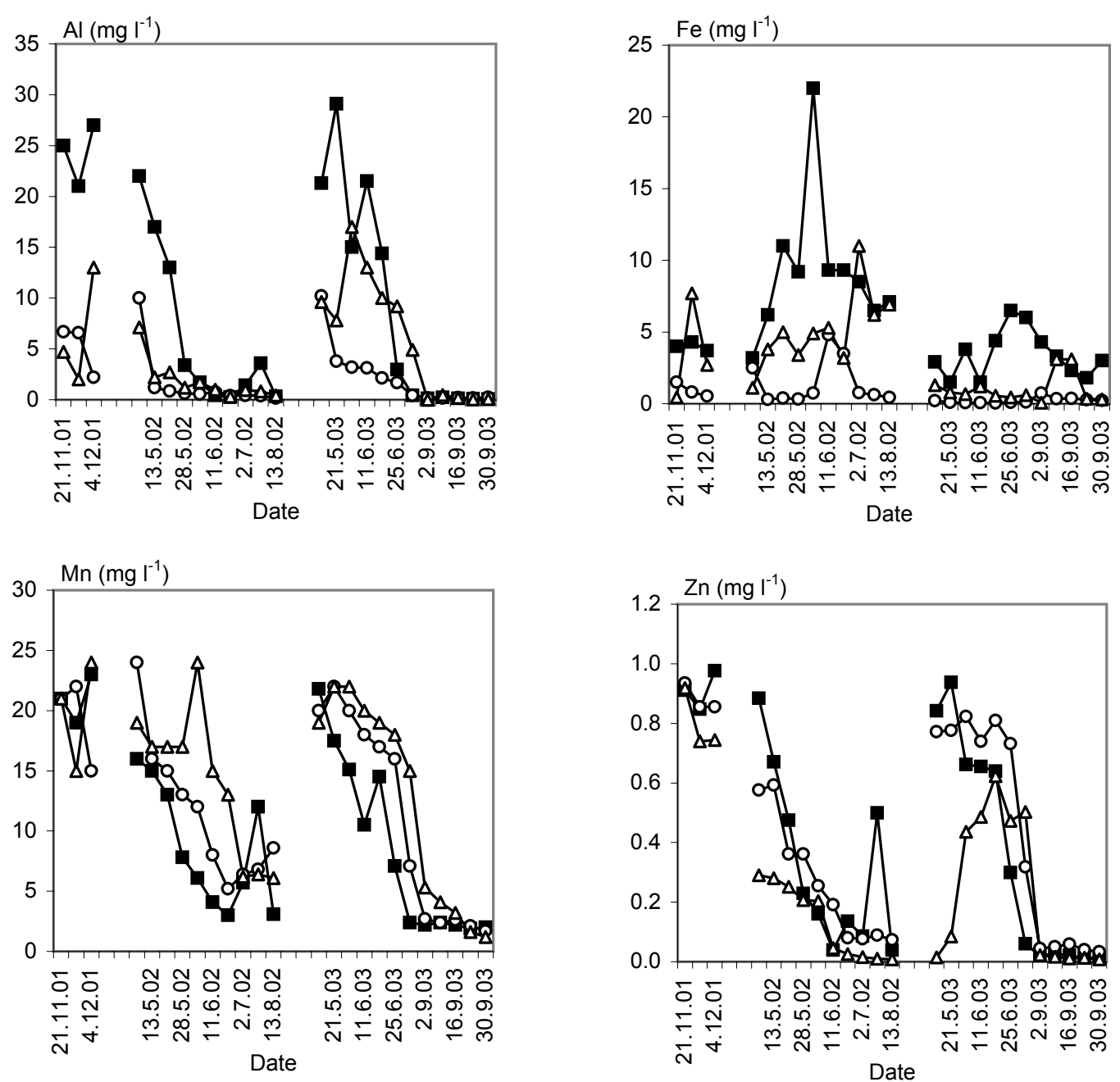

Fig. 4. Non-filtered aluminium, iron, manganese and zinc concentrations in the influent to and effluents from the treatment cells $(\boldsymbol{\square}=$ influent water, $\mathbf{O}=$ effluent from limestone cell, $\Delta=$ effluent from SAPS cell).

tenance problem and the system has been flushed only once, in the summer of 2002 , to remove precipitates from the wells.

For manganese concentrations no significant $(\mathrm{P}<0.05$, paired $\mathrm{t}$-test) reduction was observed in any of the treatment cells but following the treatment cells concentrations were periodically even higher than in inlet water. Probably this results from dissolved Mn originating from the soil walls and construction material, and the reducing conditions in SAPS cells, as in the reduced +II state Mn is relatively soluble at least up to $\mathrm{pH}$ 8. In the nearneutral $\mathrm{pH}$ conditions of SAPS cells Mn removal can only occur at well aerated solutions from which essentially all $\mathrm{Fe}$ and $\mathrm{Al}$ has been precipitated (Rose et al. 2003). It should be noted that manganese, in contrast to iron and especially aluminium, is not of great biological concern (Schiele 
Kustula, V. et al. SAPS for treatment of acid sulphate soil runoff
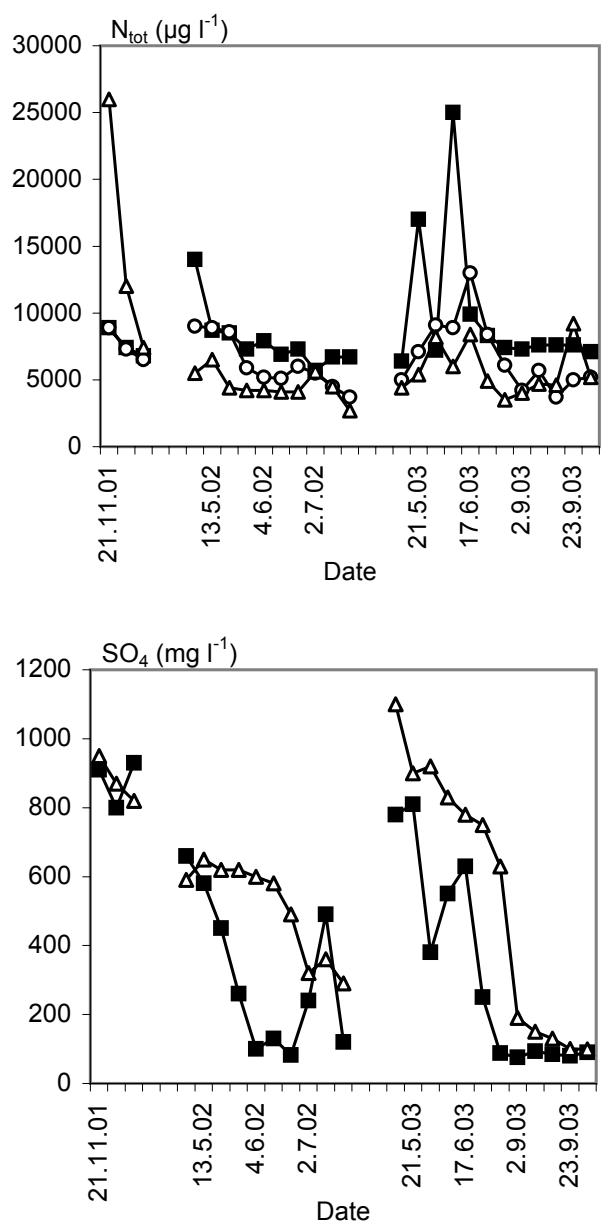

1991) and so is not of primary consideration for the design of treatment systems.

Dissolved oxygen saturation ranged from 0 $60 \%$ in the inflow water, but after the SAPS treatment cells the oxygen concentrations decreased to practically zero. Anoxic conditions are essential for the proper function of the compost and limestone layer. High dissolved oxygen concentrations are toxic to the sulphate-reducing bacteria in the compost layer and may cause armouring of the limestone layer. Following the SAPS cells the water is oxygenated in aerators and the final outflow oxygen saturations ranged between 80 and $90 \%$.

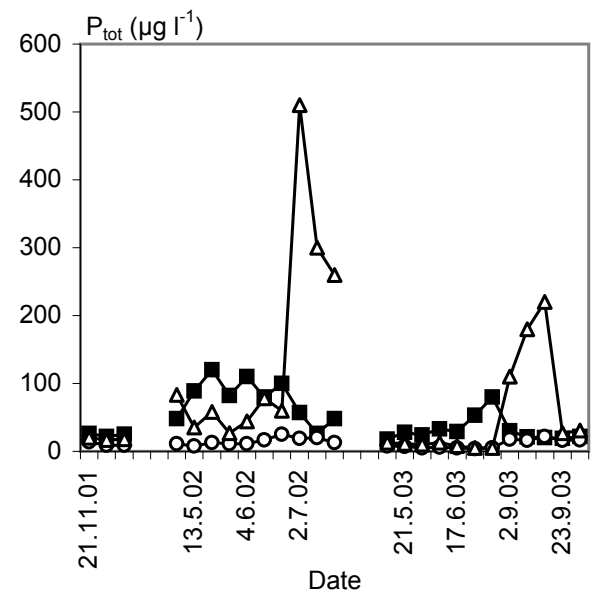

Fig. 5. Total nitrogen, total phosphorus and sulphate concentrations in the influent to and effluents from the treatment cells $(\mathbf{\square}=$ influent water, $\mathrm{O}=$ effluent from limestone cell, $\Delta=$ effluent from SAPS cell).

During the study period trace metal $(\mathrm{Zn}, \mathrm{Ni}$, $\mathrm{Cu}, \mathrm{Cr}, \mathrm{Cd}$, and $\mathrm{Pb}$ ) concentrations in the inlet water were low for most elements, with the exception of $\mathrm{Zn}$ and $\mathrm{Ni}$, near or below the quantification limit (1-10 $\mu^{-1}$ depending on element), and no leaching of metals from the reactors could be observed. Both $\mathrm{Zn}$ and Ni levels were significantly $(\mathrm{P}<0.05$, paired t-test) lowered by the SAPS treatment but not affected by the limestone treatment alone. As expected, concentrations of calcium and sulphate were higher in the effluents than in influent water. The higher concentration of calcium results from the dissolution of the limestone layer and of gyp- 
Vol. 14 (2005): 112-121.

sum added to the compost layer and that of sulphate from the compost layer.

The SAPS treatment cells initially released relatively high concentrations of nitrogen, but from the spring of 2002 concentrations of the effluent samples have been lower than the respective influent values. The exception is June-July 2002 when the systems were flushed to remove precipitates from the wells. During this period or shortly afterwards the concentrations of nitrogen and phosphorus and also some metals were exceptionally high. Since September 2003 the total phosphorus content of effluent from Cell 2 has been steadily increasing for some yet unknown reason. The gypsum material used in Cell 2, iron gypsum, contains only trace amounts of phosphorus (Varjo 2001) and is therefore not assumed to be the source.

It was expected that the main problems associated with SAPS treatment of acid sulphate soil runoff in Finland would be the seasonal variations in flow, temperature and water quality. The biological processes in SAPS treatment are temperature-dependent and the maximum flow of runoff occurs in the spring after snow thaw when the water temperature is unfavourable for biological activity. Also the large fluctuations in the flow rate and acidity do not favour the use of biological treatment processes. However, the main objective of the organic layer is to consume dissolved oxygen in the drainage water thus preventing armouring of the limestone by Fe oxyhydroxide precipitation. This mechanism worked very well. The microbial sulphate reduction is expected to produce alkalinity only during the period of warmest summer months and is of minor importance as the majority of the alkalinity in any case is produced by the limestone layer dissolved by the acidic, oxygen-depleted water. The pilot system has responded well to the rapid changes in water quality and reduced removal rates during the study period were not observed.
The pilot study will continue in 2004 and, based on current results, modifications to the SAPS reactors have already been applied: one of the reactors has been reconstructed with an additional $20 \mathrm{~cm}$ of limestone and corresponding removal of the compost to increase the water to limestone contact time, which addresses the main problem of the current system - insufficient alkalinity production.

\section{Conclusions}

The current results do not yet demonstrate the effectiveness of a SAPS system in treating drainage water from acid sulphate soils but if properly designed SAPS could be a promising alternative to direct liming of water courses at certain sites. The system is best suited for limited areas with poor water quality, so-called hot spots. One significant obstacle to the large scale implementation of SAPS systems for treatment of runoff from acid sulphate soils is the size of the required land area. This is true even though the SAPS systems are more compact than other types of constructed wetlands. Therefore anoxic limestone drains (e.g. Watzlaf et al. 2000) could be a complementary larger scale passive treatment solution for acid soil runoff in cultivated areas. The subsurface construction of ALDs allows for more efficient use of space than SAPS and the influent water could be directed to ALDs directly from subsurface drains eliminating the need of oxygen removal by organic substrate.

Acknowledgements. This research was funded by the West Finland Regional Environment Centre. The pilot plant was designed and constructed by Vesi-Hydro Oy Ab and West Finland Regional Environment Centre, respectively. Partek Nordkalk Oy Ab generously provided the limestone used in the treatment cells. The compost material was provided by Suupohjan Humustuote Ky, free of charge. 
Kustula, V. et al. SAPS for treatment of acid sulphate soil runoff

\section{References}

Gusek, J.J. \& Wildeman, T.R. 2002. Passive treatment of aluminium-bearing acid rock drainage. In: 2002 West Virginia Surface Mine Drainage Task Force Symposium Papers. Updated 1 Aug 2003. Cited 30 Jan 2004. Available on the Internet:http://www.wvu.edu/ agexten/ landrec/02TFS/Gusek.pdf

Hedin, R.S. 1997. Passive mine water treatment in the Eastern United States. In: Younger, P.L. (ed.). Minewater treatment using wetlands. Proceedings of a CIWEM National Conference, University of Newcastle, Newcastle upon Tyne, September 5, 1997. p. 1-15.

Hudd, R. \& Kjellman, J. 2002. Bad matching between hatching and acidification: a pitfall for the burbot, Lota lota, off the river Kyrönjoki, Baltic Sea. Fisheries Research 55: 153-160.

Huttu, U. \& Koskenniemi, E. 1998. Reduction of acidity in the discharge water from Rintala ompoldering at Kyrönjoki river. Regional Environmental Publications 69. West Finland Regional Environmental Centre, Vaasa. 20 p. (in Finnish with English summary).

Jage, C.R., Zipper, C.E. \& Noble, R. 2001. Factors affecting alkalinity generation by successive alkalinity-producing systems. Journal of Environmental Quality 30: 10151022.

Joukainen, S. \& Yli-Halla, M. 2003. Environmental impacts and acid loads from deep sulfidic layers of two welldrained acid sulfate soils in western Finland. Agriculture, Ecosystems and Environment 95: 297-309.

Kepler, D.A. \& McCleary, E.C. 1994. Successive alkalinity producing systems (SAPS) for the treatment of acidic mine drainage. In: Proceedings of the International Land Reclamation and Mine Drainage Conference and the Third International Conference on the Abatement of Acidic Drainage. Pittsburgh, PA, U.S. Bureau of Mines SP GA-94. p. 195-204.

Kustula, V. 2000. Treatment of acid sulphate soil drainage with biological sulphate reduction. MSc Thesis, University of Jyväskylä, Finland. 75 p. (in Finnish with English summary).

Lähetkangas, S. 1995. Acidification of river Kyrönjoki and reducting its acidity. Mimeograph series of Finnish Environment Institute 630.67 p. (in Finnish with English summary).

Meriläinen, J.J. 1989. Impact of an acid, polyhumic river on estuarine zoobenthos and vegetation in the Baltic Sea, Finland. PhD thesis, University of Jyväskylä, Finland. $48 \mathrm{p}$.

Nairn, R.W. \& Mercer, M.N. 2000. Alkalinity generation and metals retention in a successive alkalinity producing system. Mine Water and the Environment 19: 124133.

Österholm, P. \& Åström, M. 2002. Spatial trends and losses of major and trace elements in agricultural acid sulphate soils distributed in the artificially drained Rintala area, W. Finland. Applied Geochemistry 17: 12091218.

Palko, J. 1994. Acid sulphate soils and their agricultural and environmental problems in Finland. PhD thesis, University of Oulu, Finland. 58 p.
Palko, J., Merilä, E. \& Heino, S. 1988. Land drainage planning for acid sulphate soils. Publications of the Water and Environment Administration 21. The National Board of Waters and Environment, Finland. 61 p. (in Finnish with English summary).

Peltola, P. \& Åström, M. 2002. Concentrations and leachability of chemical elements in estuarine sulfur-rich sediments, W. Finland. The Science of the Total Environment 284: 109-122.

Rose, A.W., Means, B. \& Shah, P.J. 2003. Methods for passive removal of manganese from acid mine drainage. In: 2003 West Virginia Surface Mine Drainage Task Force Symposium Papers. Updated 1 Aug 2003. Cited 7 July 2004. Available on the Internet: http://www.wvu. edu/ agexten/landrec/2003TFS/Rose03.pdf.

Schiele, R. 1991. Manganese. In: Merian , E. (ed.). Metals and their compounds in the environment. $\mathrm{VCH}$, Weinheim, Germany. p. 1035-1044.

SFS 3005. Alkalinity and acidity in water. Potentiometric titration. Helsinki: Finnish Standards Association, 1981. $5 \mathrm{p}$.

SFS 3021. Determination of $\mathrm{pH}$-value of water. Helsinki: Finnish Standards Association, 1979. 4 p.

SFS 3026. Determination of total phosphorus in water. Digestion with peroxodisulfate. Withdrawn standard. Helsinki: Finnish Standards Association, 1986. $11 \mathrm{p}$.

SFS 3032. Determination of ammonia nitrogen of water. Helsinki: Finnish Standards Association, 1976. 6 p.

SFS-EN 872. Water quality. Determination of suspended solids. Method by filtration through glass fibre filters. Helsinki: Finnish Standards Association, 1996. 16 p.

SFS-EN 25813. Determination of dissolved oxygen. lodometric method. Helsinki: Finnish Standards Association, 1996. 12 p.

SFS-EN ISO 10304. Water quality. Determination of dissolved fluoride, chloride, nitrite, orthophosphate, bromide, nitrate and sulfate ions, using liquid chromatography of ions. Part 1: Method for water with low contamination. Helsinki: Finnish Standards Association, 1995. 22 p.

SFS-EN ISO 11885. Water quality. Determination of 33 elements by inductively coupled plasma atomic emission spectroscopy. Helsinki: Finnish Standards Association, 1996. $16 \mathrm{p}$.

SFS-EN ISO/IEC 17025. General requirements for the competence of testing and calibration laboratories. Helsinki: Finnish Standards Association, 2000. 47 p.

Varjo, E. 2001. Gypsum treatment in managing internal load from sediments of eutrophied lakes. PhD thesis, University of Turku, Finland. $45 \mathrm{p}$.

Watzlaf, G., Schroeder, K. \& Kairies, C. 2000. Long-term performance of anoxic limestone drains. Mine Water and Environment 19: 98-110.

Weatherley, N.S. 1988. Liming to mitigate acidification in freshwater ecosystems: A review of the biological consequences. Water, Air and Soil Pollution 39: 421-437. 


\title{
SELOSTUS
}

\section{Happamien sulfaattimaiden kuivatusvesien käsittely SAPS-menetelmällä: pilot-kokeiden alustavat tulokset}

\author{
Virve Kustula, Allan Witick ja Jarmo J. Meriläinen \\ Jyväskylän yliopisto
}

\begin{abstract}
Artikkelissa on käsitelty happamien sulfaattimaiden kuivatusvesien käsittelyyn suunnitellun koelaitoksen toimintaa kahden ensimmäisen käyttövuoden ajalta. Koelaitos on perustettu Ilmajoelle Rintalan pengerrysalueelle. Kokeiltava SAPS-menetelmä (successive alkalinity producing system) on kehitetty USA:ssa alun perin happamien kaivosvesien käsittelyyn, ja se yhdistää biologisen ja kemiallisen käsittelyn. Hankkeen takana on useampivuotinen tutkimustyö, jonka aikana menetelmää on testattu laboratoriomittakaavassa.

Menetelmässä käsiteltävä vesi johdetaan ensin kompostimassan ja sen jälkeen kalkkikivikerroksen läpi. Puhdistuksen ensimmäisessä vaiheessa kompostimassa poistaa vedestä liuenneen hapen, suodattaa kiintoainesta ja pidättää sulfaatinpelkistyksen seurauksena saostuvat metallisulfidit. Käsittelyn toisessa vaiheessa kalkkikivikerros nostaa veden $\mathrm{pH}$ :ta ja alkaliniteettia. Kalkkikivikerroksen jälkeen vesi johdetaan ilmastuksen kautta
\end{abstract}

toisiin maa-altaisiin, joihin metallihydroksidisakka laskeutuu.

Koelaitoksella on vertailtavana kolme käsittelyä: kaksi erilaista ns. SAPS-reaktoria, jotka perustuvat komposti-kalkkikivikäsittelyyn ja vertailun vuoksi pelkkä kalkkikivikäsittely. Tähän mennessä saatujen analyysitulosten perusteella kaikki tutkitut käsittelyt parantavat veden laatua, mutta SAPS-käsittelyn tehokkuus jättää vielä toivomisen varaa. Nykyisellään kalkkikiviallas on tehokkain käsittelyvaihtoehto eikä kompostialtaiden hyötyä ole vielä voitu osoittaa. Tähän mennessä saatujen kokemusten perusteella laitoksen rakenteeseen on tehty joitakin muutoksia, joiden tulokset nähdään käsittelykokeen jatkuessa vuonna 2004. Jos SAPS-käsittely osoittautuu toimivaksi, saattaa se tulevaisuudessa tarjota edullisen ja ympäristölle turvallisen vaihtoehdon kuivatusvesien paikalliseen käsittelyyn. 